UDC 811.111-26

\title{
LINGUISTIC DEVICES OF DEVELOPING TEXT FORMAL INTEGRITY
}

\author{
H. O. Matkovska \\ Kyiv, National technical university of Ukraine \\ "Kyiv polytechnic institute" \\ dandeloomis@gmail.com
}

The article provides the profound insight into the principles and means of achieving the formal text integrity. The fundamental directions of the text study have been suggested. They include the purely linguistic approaches as well as the interdisciplinary ones. The notion of text has been specified within the structural-and-grammatical, semantic, communicative and semiotic approaches. The main standards of textuality have been discussed. The integrity as one of the crucial criteria pertaining to the text is associated with the standards of cohesion and coherence. The main divergences between the cohesion and coherence have been established. Cohesion is determined as a formal aspect of the textual integrity which is concerned with the lexicogrammatic relations within the text. The coherence as a content integrity is predetermined by the text theme. It has been stipulated that the communicative unity of the text is achieved through the information flow, establishing anaphoric or cataphoric relations throughout the informative structure of the text. The research has been aimed at the organization and characterizing of the principal linguistic devices used to provide the formal integrity. The cohesion is based on the formal iteration, which involves various types of recurrence, reference, ellipsis and substitution, and formal relation that is achieved by means of conjunction and word order.

Key words: text, standards of textuality, integrity, cohesion, iteration.

Introduction. Text as a complex heterogeneous object associated with both language and speech requires profound interdisciplinary research. The insight into its structural-and-grammatical, semantic, semiotic, communicative and pragmatic peculiarities, as well as the investigation of its categories and the creation and interpretation processes have been provided within the scope of text linguistics - the philological discipline, which incorporates a set of the textual analysis branches, e. g. the study of text semantics and grammar, functional stylistic, cognitive, semiotic perspectives etc.

Text and the peculiarities of its structure have been extensively studied from the period of the text linguistic establishment during the late 1960s and early 1970s. The scientific works by R. de Beaugrande, W. Dressler, K. Brinker, R. Harweg, M. A. K. Halliday, R. Hasan and I. Galperin have formed the basis for further academic inquiry into the nature of text. Although numerous aspects within the scope of text linguistics have been researched in great detail, a substantial number of problems are yet to be solved.

The object of the article is the structural aspect of the textual integrity.

The subject is the linguistic inventory used to achieve textual integrity in its structural dimension.

To perform the scientific scrutiny we have examined the formal structure of the novels 'Mrs Dalloway' (1925) and 'To the Lighthouse' (1927) by V. Woolf and her short stories 'New dress', 'The string quartet', 'Searchlight', 'Kew gardens' and 'Solid objects' that belong to the collection of short stories 'A haunted house and other short stories' published in 1944. 
The aim of the scientific paper is to provide the detailed analysis of the lexical and grammatical means of attaining the structural unity on the level of text structure.

To accomplish the established aim, the following set of tasks has to be fulfilled:

- to identify the notion of the text from the standpoints of its structure, communicative functions and semiotic nature;

- to elicit the major standards pertaining to the text;

- to provide the insight into the category of textual integrity;

- to analyse the structural dimension of textual integrity;

- to specify the cohesive linguistic devices involved in rendering the textual formal integrity.

The ontological status of the text. The divergence of the directions towards the text studies imposes certain difficulties associated with defining the notion of text from the linguistic perspective. Various attempts have been made by the Ukrainian and foreign scholars to systematize the approaches towards the study and definition of the text. Etymologically the word 'text' developed from Latin texere, having the direct meaning 'to weave, join together, plait, braid', as well as 'to construct, fabricate, build, compose' in a figurative sense. The latter meaning, as stated by Greetham, was derived from the Greek word tikto 'to bring into the world, to engender, bear, produce'. This determines the ambivalence of the text even on the earliest stage, when the term was coined, because, on the one hand, it is derived from the lexical unit with the literal and concrete meaning of 'woven textile' and, on the other hand, being 'a work of art and both technical and imaginative procedures' in the figurative sense [6, p. 26].

The Ukrainian linguist N. Nepyivoda provides the following standpoints to define this term:

- according to the social-and-historic approach text is a cultural phenomenon and a written product that manifests the result of intellectual and spiritual practices;

- from the point of view of the social-and-psychological approach text is a means of influence on the consciousness and behaviour of a personality;

- with respect to the linguistic approach text is defined as a set of language units at different levels;

- functional-and-stylistic approach implies that text is a semantic room for embodiment of language units;

- from the standpoint of the communicative approach text is characterized as a speech act;

- in terms of the cognitive approach text is a result and way of cognition [3, p. 77].

The suggested classification brings the text out of purely linguistic domain, drawing attention to its close ties with the social, cultural, psychological and cognitive spheres.

Having analysed the definitions provided by the scientists, who work in the field of text linguistics and discourse analysis, we may assume that all of them elicit a specific feature or a number of features, which determine the concept of text. In compliance with the structural approach text is generally defined as a connected sequence of language units. For instance, K. Brinker identifies it as coherent 
sequence of sentences, whereas R. Harweg states that it is a sequence of sentences, connected by means of syntagmatic substitution [4, p. 11].

M. A. K. Halliday and R. Hasan have drifted from purely structural-andgrammatical interpretation of a text, highlighting its semantic nature. The scientists define it broadly as any passage, spoken or written, of any length, which constitutes a unified entity, being a unit of language in use. They put forward the idea that it is misleading to treat a text as a super-sentence or an extended sentence, as it does not consist of sentences, it is realized by them [5, p. 1-2]. For that reason a text is envisaged not as a grammatical unit, rather as a semantic one.

The communicative nature of a text has been elucidated in the definition formulated by $\mathrm{N}$. Valgina. She treats it as an integral unit, consisting of communicative-and-functional elements, which are organized in a system to perform the author's communicative intention according to the speech situation [1]. The determining characteristic of a text in the scope of the communicative approach is its ability to convey and store information, as well as to influence a reader.

From the semiotic standpoint a text is usually interpreted as a global sign or an aggregate of the interconnected signs, being a part of the semiotic universe. From this standpoint text is described as a conventional sign having triple structure that realizes its syntactics, semantics and pragmatics.

However, there have been numerous attempts to synthesise different approaches towards the definition of the text in order to cast light upon the most relevant characteristics. I. Galperin identified a text as product of the speech-creation process, which is characterized by its integrity and objectivise in a written form, literary elaborated in compliance with its style-and-genre characteristics; it is composed of the title and a number of special units (super-phrase unities), integrated by means of different lexical, grammatical, stylistic, and logical ties; it is also endowed with a definite pragmatic purpose [2, p. 18].

Integrity as a basic text category. Text as a linguistic entity is identified through its texture (a term suggested by M. A. K. Halliday and R. Hasan) or textuality (implemented by W. Dressler and R. de Beaugrande), i. e. a set of standards or broad categories pertaining to a text and distinguishing it from any other linguistic or extralinguistic formation. The idea to identify text through its standards has been implemented in the work by M. A. K. Halliday and R. Hasan, however they emphasise only the role of cohesion and coherence as the principal distinctive features of a text [8]. This endeavour was, however, substantially expanded by W. Dressler and R. de Beaugrande, who determined a text as a certain communicative occurrence which meets seven standards of textuality: cohesion, coherence, intentionality, acceptability, informativity, situationality and intertextuality [5, p. 11].

In the Russian and Ukrainian linguistic tradition the standards of textuality are usually referred to as the categories of a text. The first system of the text categories was elaborated by I. Galperin, who mentioned the informativity, divisibility, prospection, retrospection, cohesion, contiguity, modality, autosemantics and integrity as the inherent textual characteristics [2]. Although, at the first glance the two above-mentioned systems of standards bear hardly anything in common, both of 
them emphasise the meaning of textual unity in terms of its syntactical structure, lexis, semantic content and function.

Integrity is one of the crucial textual categories. However, W. Dressler and R. de Beaugrande did not single out it as a separate standard of textuality. It was the linguist I. Galperin who introduced integrity as an immanent category of text. According to the original definition, it is one of the constitutive characteristics of text, the comprehensive embodiment of the author's intention, being established and elicited in various narrative modes [2, p. 131]. O. Selivanova has reconsidered and expanded the above-mentioned statement, suggesting that integrity is a textual criterion, which reflects the relative insularity of its sign system, being achieved by means of the inter-level integration, content condensation and perceiving of text as a unified continual object. Apart from that she mentions that on the early stages of study this category was treated as a unity of form, content and function [7, p. 499]. Judging from these definitions the concept of integrity refers to the standards of cohesion and coherence in the classification by W. Dressler and R. de Beaugrande.

We may assume that the textual integrity is achieved on the content, communicative and structural levels. The content integrity is predetermined by theme of a text, its conceptual core; the communicative unity is achieved through the information flow, establishing anaphoric or cataphoric relations throughout the informative structure of a text. Structural integrity encompasses the formal linguistic signals, which provide the lexicogrammatical unity of a text.

Textual integrity is determined by the iteration and relation. Iteration is a repetition of signs, their forms and meanings, whereas the relation of a form and concept it encodes is defined as a system of connections that regulate the correlation between the parts of a textual unity on the levels of form and meaning. The relation of the text elements incorporates them into the unified form-and-meaning framework. The structural integrity of the text is implemented by the cohesive means on the level of form. Cohesion expresses the continuity that exists between parts of a text [8, p. 299]. It may be lexical and grammatical; it may also exhibit both lexical and grammatical features.

Formal iteration involves the referential and synonymic recurrence. Apart from that it dwells upon grammatical cohesion being based on the relatedness of form. It falls into three types: reference, substitution and ellipsis, which involve the purely grammatical devices to achieve the textual continuity. They are characterized as those being a closed system, as their use is determined by the rules of grammar.

Reference is the most common type of grammatical cohesion; it is implemented by means of replacement of a nominative unit with a pronoun or word with qualitative or quantitative meaning. For example, the passage from the novel 'To the lighthouse' (published in 1927) below provides an example of anaphoric reference, where the nominative item Mrs Ramsay is replaced with a personal pronoun she:

"Yes, of course, if it's fine tomorrow," said Mrs Ramsay. "But you'll have to be up with the lark," she added' [11, p. 3].

Substitution involves the replacement of a group of words or sentences with the words the same, likewise, so, not etc. It should be mentioned that the elements that substitute each other belong to different levels of language. This can be illustrated with the example below from the short story 'New dress' (1944): 
"They petered out respectably in seaside resorts.... And she had done the same she was just like her aunts" [9].

Ellipsis is the omission of a sentence or its part, which meaning can be retrieved from the context. The short passage from 'The string quartet' (1944) below is an example of the use of ellipsis in dialogues:

"Did you see the procession?"

"The King looked cold" [9].

Although, it is not expressed explicitly, it can be restored from the context that the King looked cold during the procession in question. This kind of ellipsis is used to avoid the redundancy and simulate the casual conversation.

Ellipsis may also bear a stylistic implication and is usually used in the stream of consciousness technique, which involves a cohesive distortion of the text. The following extract from the novel 'Mrs Dalloway' (issued in 1925) demonstrates the use of the nominal elliptical structures to fix the interior speech:

"In the people's eyes, in the swings, tramps and trudge; in the below and the uproar; the carriages, motorcars, omnibuses, vans, sandwich man, brass bands, barrel organs; in the triumph and the jingle and the strange high singing of some aeroplane overhead was what she loved; life, London, this moment of June” [10].

The entire passage consists mainly of nouns and noun phrases fixing objects and states, omitting verbs denoting action. This allows achieving a description of a momentum, avoiding any development associated with process or change of state.

Lexical cohesion involves a selection of lexical items that are related to those, mentioned in a text previously. There is a substantial freedom of choice, for the use of a certain lexical unit may be determined by the stylistic features of a text or the author's intention. Textual continuity is achieved through the iteration that involves the consequent occurrence of the same words and word-forms, words that belong to a common semantic field or antonyms and collocations.

In order to shed light on the stylistics peculiarities of the various kinds of iterations, the following examples should be considered.

"He focused it," she said. "He focused it upon the earth. He focused it upon a dark mass of wood upon the horizon. He focused it so that he could see..." [9]

This instance elicits the use of full iteration within a short passage of the text. The full subject-predicate construction consequently occurs at the beginning of the sentences in order to bring reader's attention to the culminating part of the short story 'The searchlight' (1944).

"From the oval-shaped flower-bed there rose perhaps a hundred stalks spreading into heart-shaped or tongue-shaped leaves half way up and unfurling at the tip red or blue or yellow petals marked with spots of colour raised upon the surface..." [9]

In this case we can observe the recurrence of words that belong to the same semantic field. Specifically, the lexical units flower-bed, stalk, leaf and petal have been incorporated into the semantic field of garden. They are used to describe the setting of the short story 'Kew gardens' (1944).

Formal relation is established by means of word order and conjunction. Conjunction is on the verge between grammatical and lexical types of cohesion. Although it depends on the grammar norms of a language, it involves a selection of the conjunctive expressions [8, p. 304]. The following types of conjunctions may be 
identified: additive (e. g. in addition, furthermore, by the way), adversative (e.g. however, nevertheless, despite), causal (consequently, because of this, for this purpose), temporal (then, meanwhile, from now on). For example:

“... if this engenders heat and in addition they've turned on the electric light..." [9].

This passage from 'The string quartet' (1944) demonstrates the use of the additive conjunction in addition to in order to link the idea expressed in the sentence clauses.

"The finest specimens he would bring home and place upon his mantelpiece, where, however, their duty was more and more of an ornamental nature...' [9].

In the excerpt above the use of adversative conjunction however is elicited, which is employed to express the antithesis conveyed in one clause with respect to the other.

Conclusion. Being a complex heterogeneous object, text is extensively investigated through the various perspectives. These approaches have been established the basis for the identification of text as a structural whole, composed of the interconnected and interrelated units (the structural-and-grammatical approach); as a semantic unit (the semantic approach); as a communicative occurrence aimed at conveying the author's pragmatic intention (the communicative approach); as a sign or system of signs, making it a part of the global semiosis (the semiotic approach). The nature of text is determined by predefined set of standards i.e. its texture or textuality. The standard of formal integrity or cohesion plays a crucial role in maintaining textual continuity and is implemented on the levels of formal iteration and formal relation. Formal iteration involves various types of recurrence, reference, ellipsis and substitution. Formal relation is achieved by means of conjunction and word order. The research prospects involve the study of the coherence, which alongside with cohesion determines the textual integrity.

\section{REFERENCES}

1. Валгина Н. С. Теория текста / Н. С. Валгина. - М.: Логос, 2003. -250 с.

2. Гальперин И.Р. Текст как объект лингвистического исследования. / И.Р. Гальперин. - М.: Наука, 1981. - 138c.

3. Непийвода Н. Ф. Мова української науково-технічної літератури функціонально-стилістичний аспект) / Н. Ф. Непийвода. - К.: МФА, 1997. - 356 с.

4. Селіванова О. О. Сучасна лінгвістика: напрямки та проблеми / О. О. Селіванова. - Полтава: Довкілля-К., 2008. - 712 с.

5. Beaugrande R. Introduction to text linguistics / R. Beaugrande, W. Dressler. London: Longman, 1981. -288 p.

6. Greetham D. Theories of the text / D. Greetham. - Oxford: Oxford University Press, 1999. - $581 \mathrm{p}$.

7. Hackl-Rößler S. Textstruktur und Textdesign / S. Hackl-Rößler. Tübingen: Narr Francke Attempto Verlag, 2006. - 225 p.

8. Halliday M. A. K. Cohesion in English / M. A. K. Halliday, R. Hasan. London: Longman. $-374 \mathrm{p}$.

9. Woolf V. A haunted house and other short stories [Електронний ресурс] / V. Woolf. - 2014. - Режим доступу до ресурсу: http://ebooks.adelaide.edu.au/w/woolf/w91h.html.

10. Woolf V. Mrs Dalloway [Електронний pecypc] / V. Woolf. - 2014. - Режим доступу до ресурсу: https://ebooks.adelaide.edu.au/w/woolf/virginia/w91md/ 
11. Woolf V. To the lighthouse / V. Woolf. - London: Wordsworth Editions Limited, 2002. -159 p.

\section{REFERENCES}

1. Valgina, N. (2003) Theory of text. Moscow: Logos [in Russian].

2. Galperin, I. (1981) Text as the object if the linguistic study. Moscow: Nauka [in Russian].

3. Nepyivoda, N. (1997) Language of the Ukrainian science and technology literature (functional and stylistic aspect). Kyiv: MFA [in Ukrainian].

4. Selivanova, O. (2008) Modern linguistics: directions and problems. Poltava: Dovlillia-K [in Ukrainian].

5. Beaugrande, R., \& Dressler, W. (1981). Introduction to text linguistics. London: Longman.

6. Greetham, D. (1999). Theories of the text. Oxford: Oxford University Press.

7. Hackl-Rößler, S. (2006) Textstruktur und Textdesign. Tübingen: Narr Francke Attempto Verlag GmbH.

8. Halliday, M. A. K. \& Hasan, R. (1976). Cohesion in English. London: Longman.

9. Woolf, V. (2014) A haunted house and other short stories. Retrieved from http://ebooks.adelaide.edu.au/w/woolf/w91h.html

10. Woolf, V. (2014) Mrs Dalloway. Retrieved from https://ebooks.adelaide.edu.au/ w/woolf/virginia/w91md/

11. Woolf, V. (2002) To the lighthouse. London: Wordsworth Editions Limited.

Г. О. Матковська. Мовні засоби втілення формальної інтегративності тексту.

Статтю присвячено дослідженню принципів і засобів досягнення структурної інтегративності тексту. Наукова розвідка включає аналіз головних підходів до вивчення тексту як об'єкта мовної і позамовної дійсності, що включає не лише лінгвістичні, а й міждисциплінарні напрямки. Значення терміну «текст» уточнюється у межах структурної, семантичної, комунікативної і семіотичної перспектив дослідження. Було досліджено стандарти текстуальності, серед яких виокремлено категорію інтегративності, що включає структурну (когезію) і змістову глобальну (когерентність) єдності. Когезія розглядається як формальний аспект текстової інтегративності, що визначається лексико-граматичними відношеннями у тексті. Когерентність як цілісність змісту визначається тематичною сіткою тексту. Досягнення інтегративності грунтується на взаємодії анафоричних і катафоричних зв'язків в інформаційній структурі тексту. Структурна інтегративність реалізується засобами когезії на рівнях формальної ітерації та формальної реляції. Серед засобів структурної ітерації визначено й проаналізовано лексичні повтори, референційні відповідники, еліпсис i заміщення. Структурна реляція реалізується за рахунок порядку слів у тексті й засобів кон'юнкції.

Ключові слова: текст, стандарти текстуальності, інтегративність, когезія, повтор. текста.

\section{А. А. Матковская. Языковые средства создания формальной интегративности}

Статья посвящена изучению принципов и средств достижения структурной интегративности текста. Научное исследование охватывает анализ основных подходов к изучению текста как объекта языковой и внеязыковой действительности, включая не только лингвистические, но и междисциплинарные направления. Уточняется значение термина «текст» в рамках структурной, семантической, коммуникативной и семиотической перспектив исследования. Исследовано также стандарты текстуальности. Среди них обозначено категорию интегративности, объединяющую структурную (когезию) и смысловую глобальную (когерентность) связности. Структурная интегративность реализуется средствами когезии на уровне формальной итерации и формальной реляции. К средствам структурной итерации принадлежат лексические повторы, референциальные соответствия, эллипсис и субституция. Структурная реляция осуществляется за счет порядка слов в тексте и средств конъюнкции.

Ключевые слова: текст, стандарты текстуальности, интегративность, когезия, повтор. 